\title{
T. Arakawa, A Demographic Study on the Inhabitants in Ibaraki Prefecture
}

\section{荻城縣民の人口学的研究}

\section{第 3 編 茨城県人口の社会生物学的解析}

\author{
東邦大学医学部公采箱生学教室（教授：横堀 栄)
}

荒川孝子

第 3 編に於ては相互に関聯した若干の社会 生物学的事象を全国と比較し, 或は茨城県の 各市郡別に分析綜合して, 茨城県人口を追求 したいと思う。

\section{䂰究 資 料}

前編同样国勢調查の結果を利用し昭和 25 年 を調查時期とし，24〜28 年の茨城県衛生統計 要覽及び茨城県統計珰（昭和 27 年）を主な資 料とした。本県浊農業的色柇が濃厚で, 人口 現象も自然的環境である土地，気侯等に影響 されることが大きいが，一方社会的因子と密 接な関係があることはいうまでもない，そこ でいかなる因子を指標 Merkmal として選べ ば最もよく社会環境に近似させることが出来 るかということになる．社会的因子にしても 数学的取扱いの不可能なものや, 生物学的, 経済的，交化的，社会的のあらゆる因子在集 めることは殆んど不可能である，著者は指標 として人口棈成を 9 才以下人口，10１4 才人 口，15 59 才人口，60 才以上人口の 4 階級と し, 出生, 死亡, 死产, 乳兒死亡, 婚姻, 離 婚，結核死亡，老衰死亡，就労状態，豐家戶 数, 工業化, 一世帶平均人員, 人口密度, 教 育程度, 医師数, 成年身長, 体重等約 20 の因 子を選び拊県別 $と$ 茨城県市郡別とで取捨選択 して用いることとした。

\section{研 究 方 法}

以上の種々の因子中, 4 階級人口割合は百分
比をとり，出生，死亡，婚姻，離婚は人口. 1000 対, 乳兒死亡は出生 1000 対, 死產は出産 1000 対をとつた．肺結核死亡は人口 100,000対, 老 衰死亡は人口 100,000 対 80 才以上の死亡者数 をもつてし，医師数は人口 1000 対, 就学状態 は 14 才以上人口に対する就業者数とした。

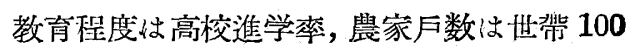
に対し，工業化は人口 1000 奶 4 人以上の工場 従菜員数, 人口密度は 1 平方籸につき, 1 世帶 本均人員は人口に対する世帶数在以てした。 成年身長，体重は 20 才時の身長，体重とした。 以上の率を以て西尾 ${ }^{5)}$ かか⿰七て府県别に用 いた方法に準じ，茨城県と茨城県各市郡の 特徴を見出さんとした。即ち

1）標準测定值を計出した。この Standardwert は各変量 $\mathrm{X}_{1}, \mathrm{X}_{2} \cdots \cdots \mathrm{X}_{\mathrm{n}}$ について算 術平均を $\mathrm{M}$, 標準偏差を $\sigma$ としたとき $\mathrm{x}_{1}=$ $\frac{X_{1}-M}{\sigma}, x_{2}=\frac{X_{2}-M}{\sigma}, \cdots \cdots, x_{n}=\frac{X_{n}-M}{\sigma}$ の $\mathrm{x}_{1}, \mathrm{x}_{2}, \cdots \cdots, \mathrm{x}_{1}$ をい, この值は大体 \pm 3 の間にありここれを逸脫することは稀でこの 值の大なることは特翼的な現像を表わすもの である.この值の大小にょり次のごとく分け てみた。

$$
\begin{aligned}
0.00 \pm 0.25 & \text { 普通. } \\
0.26-0.75 & + \text { +の時は稍々多い. } \\
& \text { 一の時は秒々少ない. } \\
0.76-1.25 & + \text { +の時は多い. } \\
& \text { 一の時は少ない. }
\end{aligned}
$$




\subsection{6一-2.50＋の時は些だ多い。 一の時は谌だ少ない。 \\ 2.51 以上＋の㭙旅めて多い。 一の㭙は極めて少ない。 \\ 折線図, 示性式}

以上の標準测定做を以て折線図を描き，更 に $\mathbf{M}$ 上り大なるを分子に，小なるを分母とし た示性式を応用して，茨城県万至市郡別の性: 質を観察した。佾示性式には各指標に関係あ る英語の頭文字を以て表わすことろした，即 b

$\mathrm{P}_{1}, \mathrm{P}_{2}, \mathrm{P}_{3}, \mathrm{P}_{4}$ (Population): 各人口割合, B (Birth) : 出生, $\mathrm{J}_{1}, \mathrm{~J}_{2}$ (Juniority)：青 年身長, 青年体重, D (Death) : 死亡, Do (Doctor) : 医師数, I (Infant-death)：乳 兒死亡, S (Still-death): 死产, M (Marriage)：婚姻, Di (Divorce)：離婚, T (Tuberculosis): 結核死亡, Se (Senility) : 老襄 死亡, Hs (High school): 高校進学率, W (Work) : 就労率, F (Farmer) : 農家戶数, Fa (Factory): 工掌化, H (Household) : 世蝥の大いさ，De (Density)：人口密度 である。

\section{相関分類表}

各訪郡別の各因子間の相関係数妾計算して， .順相関と逆相関を分類した。

\section{人口構成型式}

人口構成の 4 階級組合せによつて 人口構成 式 9 種を得, これによつて各市郡を幼若, 成 長，成熟，老襄，出稼，都市型に分㚈，これ らの型と各社会的因子との関係克た。

農村と大都市とは年令構成，日常の作㐟， 教育水準, 生活環境, 風俗, 習䟺, 医療厚生 施設に差巽があり，これらの社会的因子が人 口学的にいかに影響するかといふことは興味 あることである。選択した各指標の関係を以 上の方法によつて整理し分析追求した。

\section{全国より見た茨城県の観察}

図9に於て標準测定值による折線図，示性
示胜 武

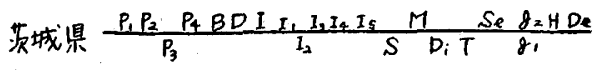

摽㻗测定值

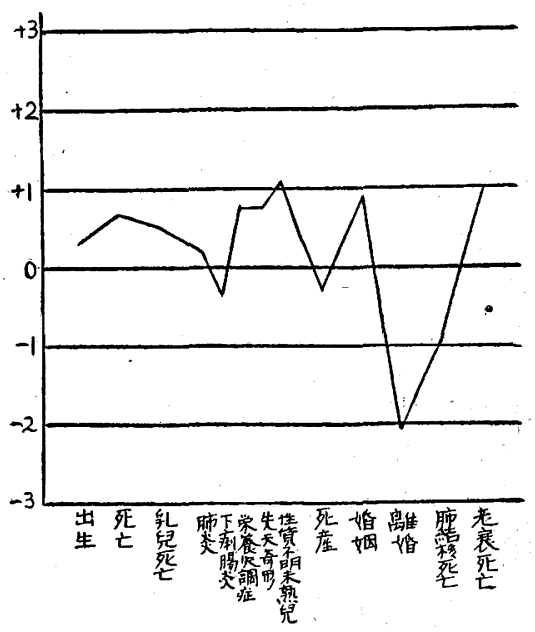

図 9 示性式と標隻測定值

式をみると，本県は中年人口の少ない出稼型 ともいふ心゙き人口檏成型で，多產，多死を示 している。そして公衆衛生発達状沉を最も敏 感に反映する指標としての乳兒死亡率の高い ことが注目される。死因別には米熟兒，先天 奇形，栄養失調证，肺炎も全国平均を上呬り， 標準測定值も大である。死產骀少ない，全国 的に死産の增加は性道德の低下, 性病, 人工 奷娠中絕による增加と死產届出の励行による とされている。本県の少ないのはこれらの事 項に反するためと侾光られる。また婚姻は多 いが離婚は少ない。この婚姻と離婚について い获福 26)がのべているが，殊に離婚について は生活水準や経济状態を反映するもので戦後 家族㸝度の廃止によつて 漸次都市化されつ了 あるとはいえ，まだ本県が封建的家族制度下 にあることを示すものであらう。また結核死 亡少く，老襄死亡は多い。体位をみれば身長 は低いが体重は大で農村の所謂厷胸型を示し ている。その他荻城県に於ける医師数は人口 
1000 対 0.64 , 工場従業員数は人口 1000 対 2.12 ,

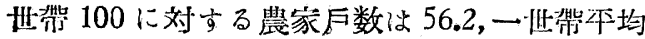
人員は 5.43 ，人口密度は 3.35 ある。茨战県 は出生，死亡が多く，都市化，重策化傾向が 遅延している現象が見られるのである。

\section{茨域県市郡別観察}

本県は図 10 のごとく町村合侀以前の昭和25 年の行政区劃は 4 市 14 郡に分礼ている。各市 郡の佔別性を表わすために標準测定值による 折線図，及び示性江により分類比较した。各 市郡について特徵的なことについてのべたい。

1) 水戶市

茨城県県庁所在地でその社会的環境 的で，それが人口丵成その他にみることが出

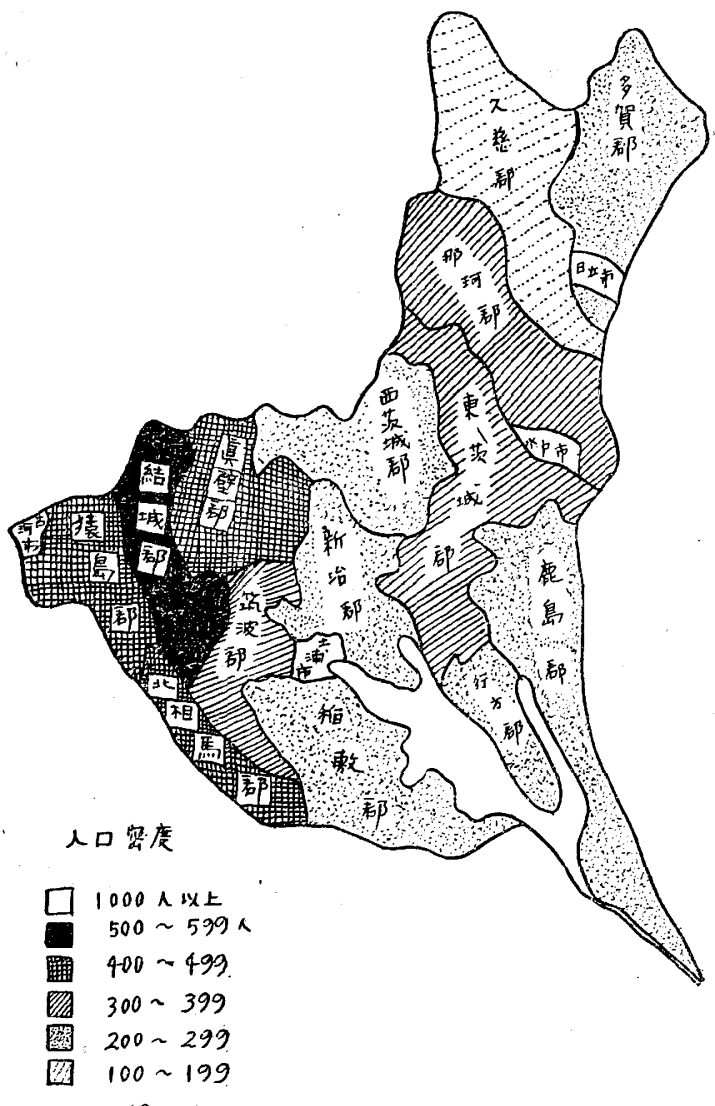

図 10 荻城県市郡別人口密绻（炤利 25 年）
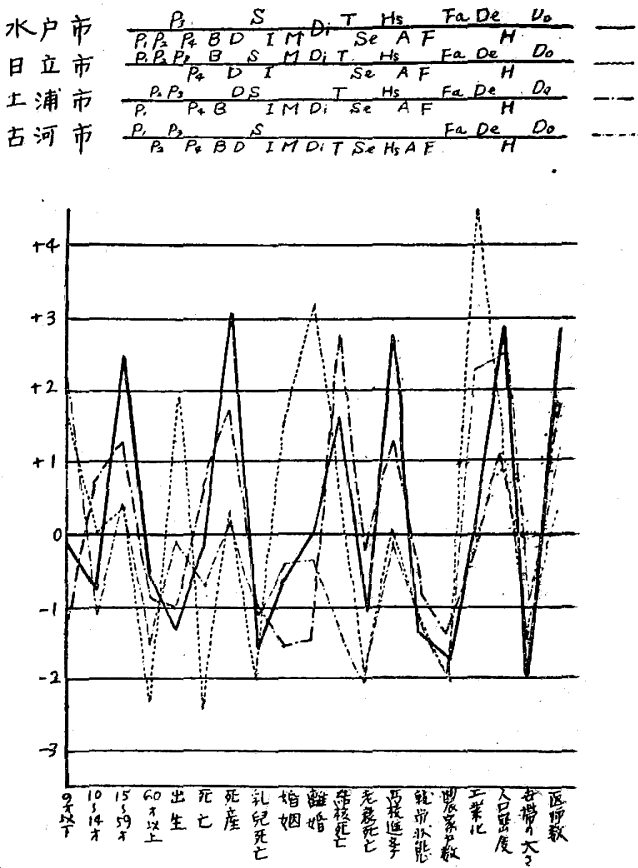

図 11 水戶市，日立市，土浦市，古河市の 標潗測定值及び示性式

来る。即ち図 11 に於て中年人口が甚だ 多く出生，死亡少く，死產が極めて多 い. 教育程度は高く, 就労率は低い。農 家戸数は忨げ少く，工場従䘬員数は普通 程度，世帶の大いさは甚だ小で，人口密 度は極めて大である。この他都市化因子 を具供してをり，標準测定值は大きく， その特殊性:老浮出させていることは注目 される。

2）日立市

茨战県工業地を代裴する嘟市として， 図 11 のごとく老人人口が極めて少なく， 幼若，青壯年厤が多い，多商少死，乳兒 死亡，老㐮死亡少く，死產及び結核死亡 は多い。また婚姻，離婚は其に多い，工 場從菜員数か：異例的に高いことはこの都 市の特徵である．就労割合の少ないの は，筫金労妝者加多く，完全失業者が多 


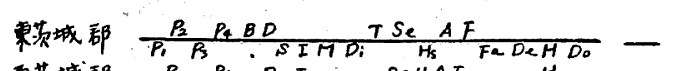

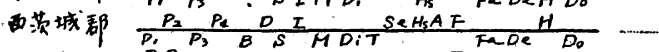
AP珂部 $\frac{P_{1} P_{2} P_{3} B S M D_{i} T S e H_{5} F \text { FaDe } D_{0}}{P_{3} P_{4} B D S I M} \cdots$

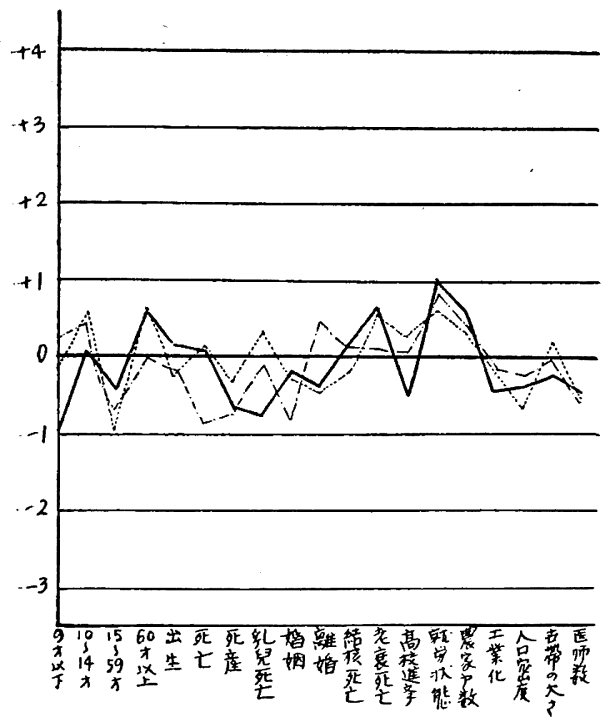

図 12 果荻城郡, 西荻城郡, 那珂郡の 標潗測定值及び示性式

久慈部 $\frac{P_{2} P_{4}}{P_{1} P_{3} B D S I M D_{i} T \text { Se } H_{s} A F \text {. FaDe Do }}$

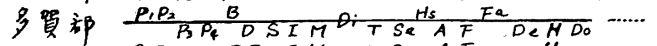

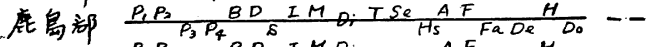

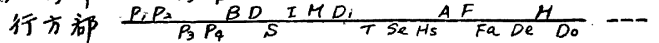

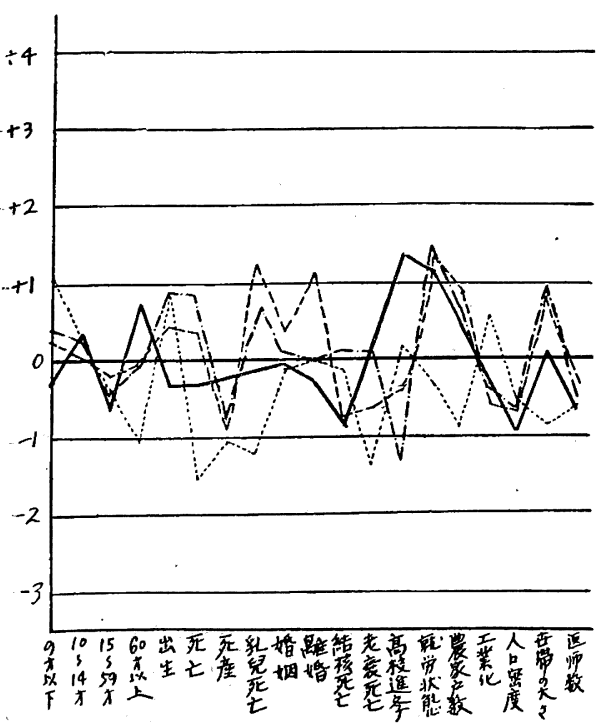

図 13 久意郡, 多賀郡, 鹿島郡, 行方郡の 標準測定値及び示性式

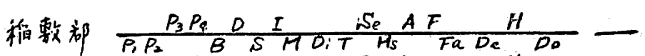

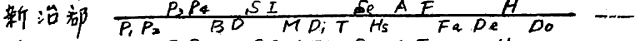

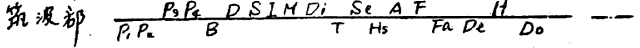

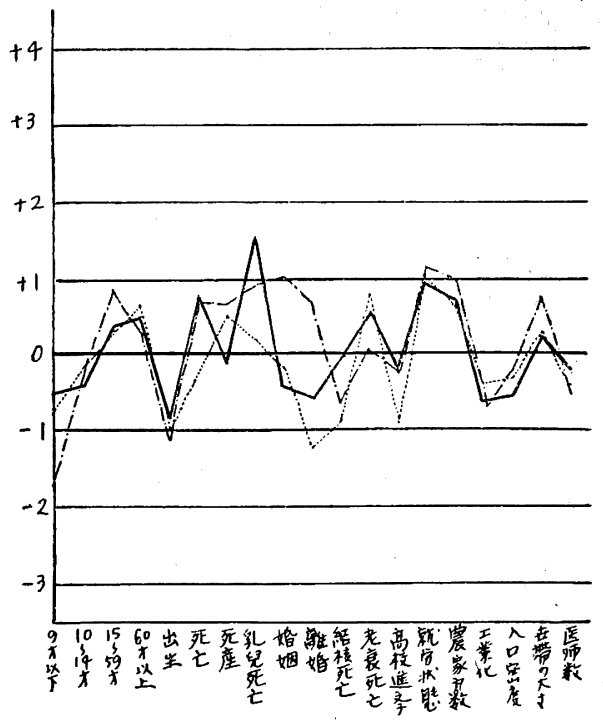

図 14 稻敷郡，新治郡，筑波郡の 整染測定值及び示性式

畚壁部 $\frac{P_{1} P_{2} P_{4} B D I M D_{i} \quad A F D_{e} H}{P_{3}}-$

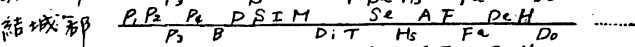

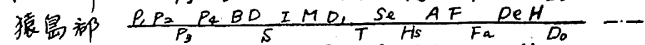

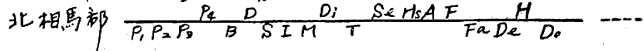

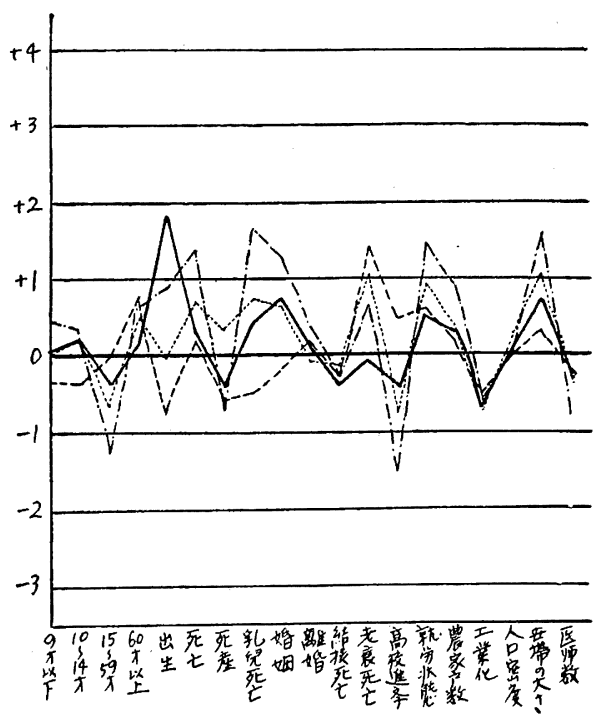

図 15 真壁郡，結城郡，猿島郡，北相馬郡の 標潐測定值及び示性式 
いためと考えられる。

3) 上淤过

小帅年人口多く，死產，結核死亡の高いこ とが見られ，農蒙戸数少なく，工場従紧員数 も多くない，かつて軍基地として，また漁䅈

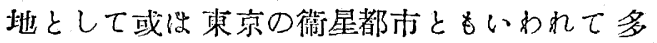
元的発達をし，都市化傾向は比較的濃厚であ る.

4) 古河市

9 才以下人口割合坊極めて高く, 老人人口は 少なく，人口学的に日立市に㔼するもののよ うである。出生, 死亡は普通かや了少ない程 度で，乳兒死亡，結核死亡，老衰死亡は何れ も少ない。婚姻も離婚も多くない。

\section{5）郡部の峴察}

その個々については図 $12,13,14,15$ を以 詳述はさけることろするが，標準测定值は小 さく，各郡部の個別的特殊性は市部程ではな く皇くて低調である。

標準测定值亚びに示性式と相俟つて郡部を 南北各 7 郡宛に分けて 市部の綜合的都市化傾 向因子の数を 15 として 観察したのが裴20で ある。これによると北地区多賀郡は日立市に 延長した工業地として 都市化因子の数は最も
多く，漁萪地である塵島，行方郡は少ない。

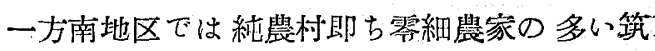
波，猿島郡や小規模な家队正的副業の存在 する真篮，結城郡は都市化傾向低く，都会と の交通便利な北相馬，新治郡は都市化因子の 数は增玑している。

\section{各社會的諸因子間の相關係數}

西尾 ${ }^{5)}$ は本邦 47 低県の社会生物学的各指標 の相関係数を計算して綜合的に観察している。 水島 ${ }^{27)}$ は出生率に及ぼす社会生物学的諸因子 の影響について，小松 ${ }^{28)}$ は死亡率, 出生率, 孚兒死亡率相互間の相関係数について，この

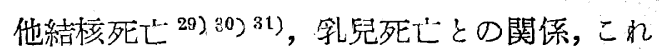
らの社会生物学的研究が多く発表されている.

著者は茨城県市郡別の人口静態, 動態の各 指標間の相関係数を計算して表 21 , 図 16 のこ とく順相関と逆相関に分類した。“各市郡の標 準测定值について相関係数を計出したが，市 郡18という少数であり，その地域による偏差 が大きく，相関係数の値のみでは有意性を断 することは出来ないまた資料自体が偶然的 事象に大きな影響があるので資料そのものの 選択から是正す心゙き点も多々ある。しかし各

裴 20 都市化傾向判別表（茨城県）

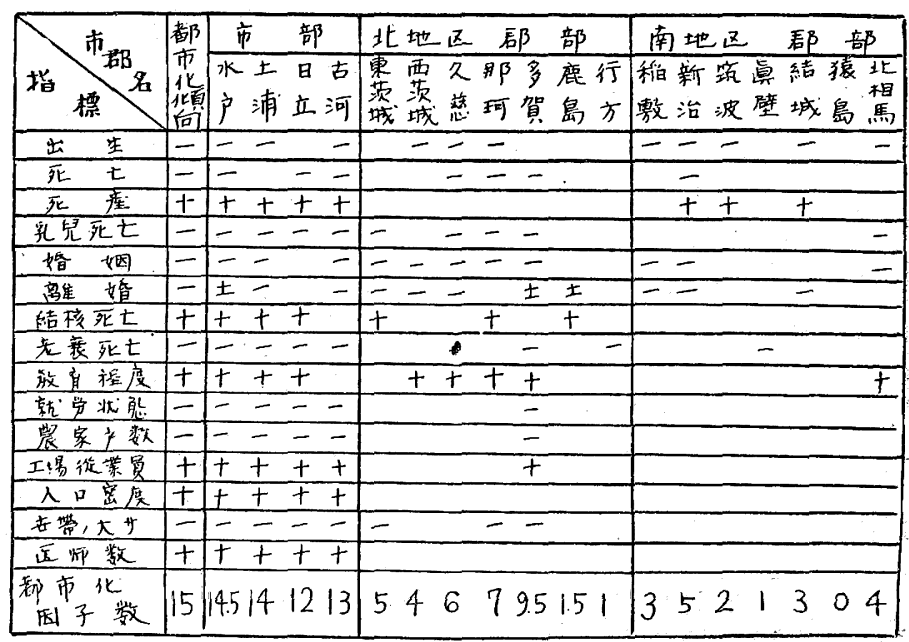


表 21 各指標間の相関分類表（茨城罧）

\begin{tabular}{|c|c|c|c|c|c|c|c|c|c|c|c|c|c|c|c|}
\hline 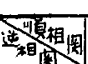 & 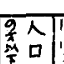 & & $\begin{array}{l}15 \\
59 \\
59\end{array}$ & 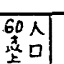 & \begin{tabular}{|l|} 
出 \\
\end{tabular} & 死 & 死 & 筧死 & 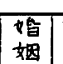 & \begin{tabular}{|l|} 
離 \\
\end{tabular} & & 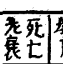 & & & 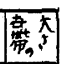 \\
\hline & & & & & \begin{tabular}{|l|}
0.57 \\
\end{tabular} & & & & \begin{tabular}{|l|}
0.12 \\
\end{tabular} & 0.46 & & & & 0.42 & \\
\hline 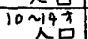 & & & & & 0.13 & 0.06 & & 0.11 & & & 0.111 & 0.16 & & & 0.12 \\
\hline 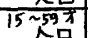 & & & 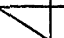 & & & & 0.80 & & & 0.03 & \begin{tabular}{|l|l|}
0.45 \\
\end{tabular} & & 0.60 & $\mid 0.67$ & \\
\hline 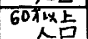 & & & & 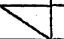 & & 0.57 & & 0.66 & \begin{tabular}{|l|}
0.05 \\
\end{tabular} & & & 0.79 & & & 0.60 \\
\hline 出生 & & & 0.44 & $\mid 0.39\rceil$ & 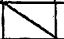 & & & & 0.41 & 0.57 & & & & & 0.17 \\
\hline 死 & 0.51 & & 0.10 & & 0.28 & & 0.01 & 0.76 & 0.08 & & & 0.59 & & & 0.57 \\
\hline 死 & 0.24 & 0.15 & & 0.25 & 0.05 & & $\infty$ & & & & 0.58 & & 0.57 & 0.79 & \\
\hline 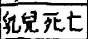 & 0.36 & & \begin{tabular}{|l|l|l}
0.42 \\
\end{tabular} & & 0.05 & & 0.43 & 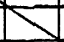 & 0.31 & & & 0.70 & & & 0.91 \\
\hline 婚姻 & & 0.03 & 0.22 & & & & 0.18 & & $\Delta$ & 0.46 & & 0.05 & & & 0.43 \\
\hline 䑾㛭 & & 0.02 & & 0.40 & & 0.43 & 0.18 & 0.18 & & 1 & & & & & 0.00 \\
\hline 繥接死亡 & 0.21 & & & 0.30 & 0.11 & 0.02 & & 0.44 & 0.22 & 0.07 & 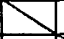 & & 0.50 & 0.43 & \\
\hline 老衰死 & 0.63 & & 0.36 & & 0.32 & & \begin{tabular}{|l|}
0.24 \\
\end{tabular} & & & 0.41 & 0.00 & & & & 0.47 \\
\hline 䖍育程度 & 0.02 & 0.09 & & 0.21 & 0.59 & 0.26 & & 0.64 & 0.39 & 0.12 & & 0.12 & & 0.66 & \\
\hline 人口密度 & & 0.29 & & 0.65 & 0.08 & 0.27 & & 0.76 & 0.03 & & & 0.61 & & $\infty$ & \\
\hline & & & & & & & 0.60 & & & & 0.38 & & 0.721 & & \\
\hline
\end{tabular}

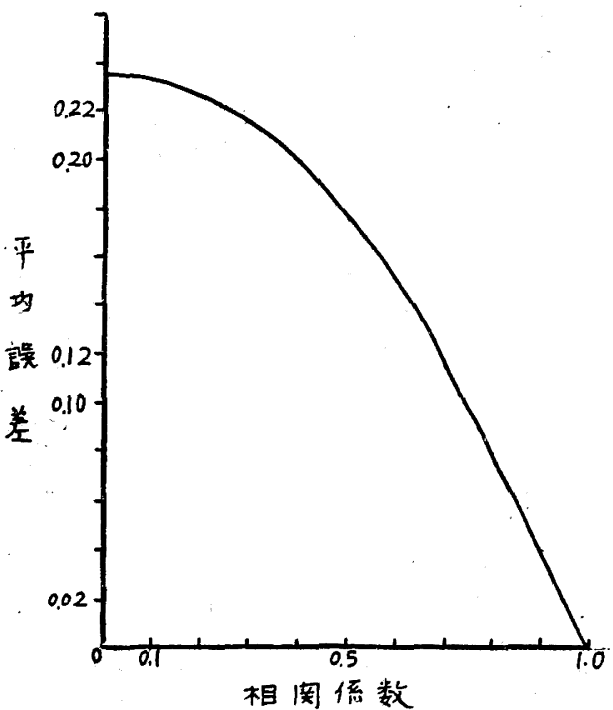

図 $16 n=18$ に対する相関係数の本均誤差

諸因子間の絕対的でない相対的関係をみてそ の表現している意義を考察することはできる。

相関分類表から相互に順相関にあるものは

第一群：9才以下人口割合, 婚姻, 離婚

第二群：10〜14 才人口割合，並びに 60 才以 上人口割合，死亡'，乳兒死亡, 老害 死亡', 一世搟平均人員

第三群：15～59 才人口割合, 死產, 結核死亡，
人口密度, 教育秙度

逆相関にあるものは

第 1 群： 9 才以下人口割合，老衰死亡，教育 程度

第 2 群：10〜14 才八口割合並びに 60 お以上 人口割合, 死紊，離婚

第 3 都：15 59 才人口制合，乳兒死亡, 出生 に分けられる。 以上の相関係数の值加ら相関 ありと断定し得ないことは前述したがここの相 関係数の值がどんな值を超えたら相関関係あ りと認めてょいかの規準によると， $\mathrm{n}-2=16$ であるから,相関ありと認められる相関係数 $\mathrm{r}$ の最小值は 0.482 であるという規準によると， 第一洋で比較的高い相関ありとい光るのは，9 才以下人口割合と出生, 出生と離婚である。 婚姻と離婚は 0.46 である.第二群では 10〜14 才人口割合より 60 才以上人口割合に高い相関 関係をみる。中でも乳兒死亡，死亡，老衰死 亡, 世乖の大さは 0.60 前後の高い相関にある。 第 3 治作では 15 59 才人口割合と死產が高い相 関々係を示し，他の因子は相互に 0.50 前後の 相1関係数である。次に逆相関では，相関係数 は小さく有意性:封断することは出来ない，個 々について心 9 才以下人口舦合と老襄死亡, 60 手以上人口制合と人口密度，乳兒死亡と教育 
程度等が逆の相関々係にあるといい得る。各 因子相互間は偶然的現象に左. 右されたり，間 接的に相互䦥に関係を有しでをり，高次の重 相関，部分相関係数を以てょり信賴出来る数 值が得られるかも知れないか，風士，気候等 の自然的環境及び風俗，㥜慣等有形然形の種 々錯綜した諸条件によつているものであつて みれば当然各因子の選択によつてこれらの教 偭は変化する訳である。

\section{$\wedge$ 口構成型式}

\section{1) 第一型 $\frac{\mathrm{P}_{3}}{\mathrm{P}_{1} \mathrm{P}_{2} \mathrm{P}_{4}}$}

中年人口か殊に多い都市型で，水戶市がこ れに属している。これに準する準都市型とも いふべ中年人口の最も多く，10〜14才人口 割合も_上廻るもの即ち- $-\frac{\mathrm{P}_{2}}{\mathrm{P}_{1}} \frac{\mathrm{P}_{3}}{\mathrm{P}_{4}}$ 型に土 浦市がある。

\section{2) 第二型 $\frac{\mathrm{P}_{1} \mathrm{P}_{2}}{\mathrm{P}_{3}}$}

第 1 型と逆で，生產年令人口割合の少ない もので出稼型で, 猿島, 結城, 真壁部である。

\section{3) 第 3 型 $\frac{\mathrm{P}_{4}}{\mathrm{P}_{1} \mathrm{P}_{2} \mathrm{P}_{3}}$}

老人人口の多い老袈型で，北相騎郡がこれ を代表している。また人口槥成上第二，第三 型の移行型ともみられる老人人口が多く生產 年令人口の少ない割合か：不鮮明なものとして 老衰出稼型 $\frac{\mathrm{P}_{2}}{\mathrm{P}_{1}} \mathrm{P}_{3} \mathrm{P}_{4}$ がある.東茨城郡 が最も老王型に近く，西茨城，久慈郡の順に 出稼型に近くなつている。

\section{4) 第 4 型 $\frac{\mathrm{P}_{3} \mathrm{P}_{4}}{\mathrm{P}_{1} \mathrm{P}_{2}}$}

中，老年人口の多い成熟型で，稻政，新治 筑波郡加これに属している。

\section{5）第 5 型 $\frac{\mathrm{P}_{1} \mathrm{P}_{2} \mathrm{P}_{3}}{\mathrm{P}_{4}}$}

幼少，中年人口の多い成長型で，日立市が この型で老人人口が少ない。これに準するるも
のとして 10〜14 子人口割合か;平均を下迴るも のに古河市がある。
6) 第六型 $\frac{\mathrm{P}_{1} \mathrm{P}_{2}}{\mathrm{P}_{3} \mathrm{P}_{4}}$

幼少人口の多い幼若型で那珂, 多賀, 豦島, 行方郡である。

以上各型に属する各市郡は地理的に接近し て赼そそれぞれ基通した特徽が存在する。

\section{各社会的諸因子と人口構成型}

以上の人口構成型と各社会的諸因子との関 係は次のごとくである。

1) 出生との関係

人口学的に幼箱に出生多く，老襄，成熟 型に低にことは当然であるが，文化線と出生 率とは逆行するといわれており，都会型に低 下し，出稼型では高くなつているのがみられ る.

2) 死亡と莫関係

死亡については戦後大いに改善されて来た 肪，乳兒死亡，老衰死亡は出稼，成熟，老衰 型に高く，成長型では低い。

3) 乳兒死亡との関係

出生率低下と共に乳兒死亡率も低減ずる訳 であるが、久保 ${ }^{22}$ ) がその原因について 11 項 目をあげて検討し，多くの原因の中，生活程 度が最も大きな影響があると述べている。生 活程度の上昇によつて 乳兒死亡低下を期待し 得るわけである。乳兒死亡の低いのは都会， 成長，老䧶型で，出稼，成熟型は高くなつて いる。

4) 死荤との関係

死產は近来自然死斑の外に人口姡娠中絕に よるものが多く，都会，成長，成熟型は高く， 低いのは出稼, “幼宕, 老哀型である。

5）婚姻，離婚との関係

婚姻，離婚は戦後斯常に高率を示したが， 漸次安定しつ了あり出稼型高く, 都会, 成熟, 老衰型は低い。 
6) 結核死亡との関係

結核死じの高いの都会型で，出稼，成熟， 老変型は低くなつている。

7) 老衰死亡との関係

結核死亡と逆で，出稼，成熟，老衰型に高 く，都会，成長型に低い。

8）就学状態との関係

就労状態はその地城に於ける自然的，社会 的環境，景気変動；㵶種等によつて基なつて くる。都会，成長型が低いのは，商策不振に 件亏㕍用労働者の失筷增加加考元られ, 出稼,

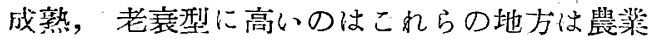
従事者が多いこと了人口過剩によつて不安定 雇用の形の就策增加が洘えられる。両孝何れ も一般に就学水蕉の低下を来す虞れが亩る。

9）教育程度，工筷化，医昞数との関係

これら㞲都会型に高く，出稼，成熟型に低 いことは共通している。なほ工莱化，医師数 は成長型に高く，幼若，老衰型に低い，教育 程度は老襄型に高くなつていることは，県の 最西南端の北相馬郡加；東京との交通便利なこ とや都市化因子を具供しているためと考えら れる。

10）人口密度，性帶の大さとの関係

人口密度と世帶の大さとは逆相関にあるも のであるが，出稼型が両者共高くなつている ことは人口收容力の飽和状態を意味している ちのとして注目される。人口密度か嘟会, 成 長型に高く，老衰，成熟型に低いこと，一世: 帶平均人員がこれと相反していることは当然 考えられることである。

\section{要 約}

以上綜合的に観察すれば，茨城県に人口飽 一和の域に達しており本県目体出稼型と考えら れ，他の社会生物学的現象仁もこれ想認める ことか出来る。文化の程度の低い嶄村的色彩 の濃厚な部分と都会的風潮の影響にょつてそ の様相はかなり複雑である。これは人口学的 に苼壯年出稼によつて 老人人口の霄的した郡
と果北部の幼型型の存在によつて再認し得る。 そしてこれらの人口構成型は各社会現象の段 階に一政した現象型であることが観察された。

\section{第 1，2，3，紑の結語}

我国公衆衛生の䂺究は断片的であつて，あ る领域に於て綜括される段階に達したものは 少い。ある面に於ては精細に研究されている が不均衡な点が多い。また疾㿑や健康状態の 社会的条件の分析《研究の㖥難性：非科学性: のため永い間放置されていた。また社会生物 学的研究があつても1〜2の因子についてのみ 論ぜられてきた，例えば一地方の乳幼兒死し の原因を論する場合に法住宅，栄養，医爒施 設のみが過大視され多くの医学的，社会的因 子の聞の関係，交通，各因子の影響の程笠等 は全く等閉視されて来た。云礼故われわれか～ 一地方の保健政策を樹立与る場合常に生物学 的, 医学的因子と社会的因子の相互のょり包 括的な，より高度な綜合の下に理解し対策を 考えていく必装がある。

著者は自分が現住勤務する茨城県の，公衆衛 生の診断的指標である人口現像走，上記の観 点加ら出来得る限りの社会生物学的因子克考 虑し，三篇に分ち調查し次の結論を得た。

1. 第一篇に於て，昭和 25 年の 国勢調查の 結果に基き，茨战県の簡易生命裴を作成して 人口現象を観察した結果は炏のごとくである。

a) 荻城県の人口䄯成は幼若及び老年令が突 出し 30 才前後の部分が陷凹している。昭和 25 年の死し率は男 12.68 , 女 11.73 で，全国より 高率である。年令別では幼䈐年令に高く，30 〜 45 才の女の死し数並びに老年令部分の死亡

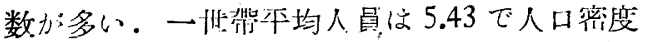
は一平方粁につき 334.82 で何れも全国平均よ り漓い。

b)'生命表汇於て, 死亡率泣前年より全年令 に亚り低い，また男女の美は僅少である。，q0 は全国に比しはるかに高率である。これに反 
し $\mathrm{q}_{1}$ は低く, $\mathrm{q}_{1}-\mathrm{q}_{4}$ は高い.

c) 生存数は全国より 30 才まで訬ないか， 舁は 35 求より，女は 60 求より多くなつてい る、生存数の男女の差は少ない。

生存比で $\frac{l_{5}}{l_{0}} \times 100$ は男女共全国より小さ W.

$l_{20} \times 100$ は男女とも全国と殆んど美かな w.

$\frac{l_{40}}{l_{20}} \times 100$ は全国よりまさり, $\frac{l_{55}}{l_{40}} \times 100$, $\frac{l_{70}}{l_{55}} \times 100$ も同様に大きい。

$l_{0}$ 加牛減する年令は罗は 65～66, 女は 69〜 70 で前年より僅かに延長している。

d) 平均余命は $\mathrm{e}_{0}$ は男 57.93, 女 60.86 で, 全国よりや了少る。 $\dot{\mathrm{e}}_{70}$ も短い。

2. 第二編に於ては人口動態と主荘死因の年 令别変化について考察し，六の如き結果を得 た.

a) 出生については人口 1000 対出生率は 29.1 で漸次聥減傾向にあるが全国より高率である。 合理的な標準化法による安定人口州生率であ る真正出生率沈 28.5 である。

b) 死しは粗死し率 12.2 , 訂正死し率は 11.7 で死因别に結核死し势除き，他の主装死因は 全国より离い。真正死亡率は 11.3 である。

c) 人口增加については自然增加率は粗率は 罗女共に 17.63 ，女のみでは 16.43 で，真正人 口自然霄加率治 17.19 である。

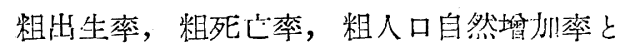

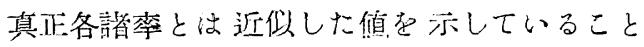
力特徴的である。

純胿生商率は 1.673 , 一代の長さは 30.22 故 30.22 年で 1.67 倍ますことを亦し, 全国より人 口增加は大きい。

d）乳兒死亡は関果更び周辺の県の首位き示 し，昭和 25 年は出生 1000 対 68.22 である。 $\alpha$ -index 惊小さく先天性系統の死因に基くもの
が大であることを示す。

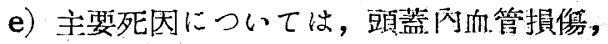

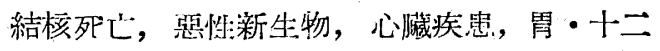
指腸・腸・大腸炎の各年令別死亡率の変化は， 結核死亡か;全国よりはるかに下迴る他は, 全 国に比し啇率で，特に心藏疾患が男女共に多 く青壯年女子に殊に高い，胃，腸炎已上超つ ている。

3. 第三綿に於ては茨城県人口を社会生物学 的に，付県別或いは茨城県备市郡別に分析綜 合宁ことによつて追求した。

a) 全国より見た茨城県人口現象苍観察した 結果は次のことくである，標準测定值による 折線図，示性式についてみると多産多死，乳 兒死し多く，死商は少ない。婚姻は多いか離 婚は少い: 結核死亡少く，老衰死亡蛙多い。

体格るみれば広胸型である。人口棈成は中 年人口の少ない出稼型を示している。

b) 茨城県市郡別観察については，水戸市は 少商少死，都书化因子を具供してをり標準測 䇥值は大である。日立市は幼若青壯年層多く

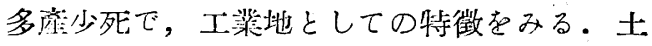
浦市は死髉，結核死亡高く，都市化傾向は濃 厚である。古河市は新與工篓地として，人口 学的その他日立术に準ずる。乳兒, 結核, 老 衰死しは何れも少ない。

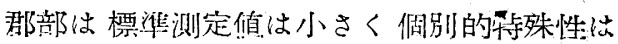
市部程でない，北地区が南地区より都市化傾 向大で，純臀村，漁村地区は都市化傾向は低 w.

c) 社会生物学的各指標の相関係数を計出し 七順相関と遊相関分分類し更に相互に相関関 係にあるものを各三满に分汁た，逆相関より 順相関にあるものが高い相関係数を示し，第 一灌の 9 甫以下人口割合と出生, 出生と離婚, 第二粦の 60 才以上人口割合, 乳兒死亡, 死亡,

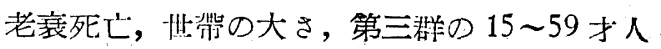
口割合と死產に高い相関関係を示した。

d）人口構成型は第一型は都市型，第二型は 
出稼型，第三型は老襄型，第四型は成熱型， 第五型は成長型，第六型は幼若型に分け，各 市郡をそれぞれ分類した。各型に属市る各市 郡は地理的に接近し，その特徵を示している。

e）各社会生物学的因子と人口構成型につい ては，出生は幼若型に多く，老衰，成熟型に 少ないままた都会型に低く出稼型に高い。死 しは乳兒死亡, 老害死亡の多い型心高く, こ れに反する成長型は低い，乳兒死亡の低いの 怯都会, 成長, 老景型で, 出稼, 成熟型は高

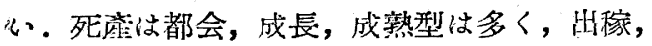
幼若, 老襄型は少い, 婚姻, 離婚は出稼型に 高い，結核死亡と老衰死亡とは相反してなり， 都会型 $と$, 出稼, 成熟, 老襄型に分们られ高 低がある。就労状態情都会, 成長型に失簿多 く, 出稼, 成熟, 老襄型注高い就学率を示 している。人口密度と圮帶の大さとは逆相 関にあるものであるが出稼型は両者ともに高 い.

上述せる茨城県生命表及び 人口動態 $と$ 主泪 死因，更に社会生物学的解析によつてみれば， 本県に於ける人口扶䓹力の堆加も限界に澾し た観があり，人口の都会地への移動が賭折し て人口そのものは本衡を保たざる弆得ないで あらう・そして県民の生活に対する欲求が現 在のま了で何等かの间上改革がなれないな らば発展の可能性は極めて少ないと拷劣られ る.出生率を減退せしめ, 非交化的死亡を減 少せしめる社会環境並びに個人生活の向上をを 期街して，本論文をその基礎的資料としたい。

\section{文献}

1. 水島治夫, 楠川晃, 瞪本隆：第 3 回府県別些 .命装，衞生統計，4 1，14, 昭和 26.1.

2. 水易治夫, 谷口芳徳: 六大都市 (具意, 大阪, 察都, 名古屋, 横浜, 神戶）任民の生命䒾、第

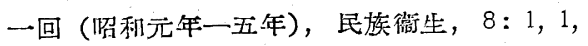
炤 15.3 .

3. 上田フサ, 石田保広: 職業別简易生命誌, 厚 生の指標, 特箱管 1 号, $2: 7,20$, 炤 30.7 .

4. 福田邦三，皇山一平，宮川清，佐川喜一：長

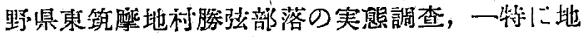

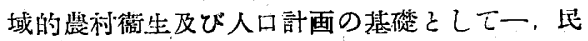
族唯生，21:2, 45, 昭 29.11.

5. 西尾硒：本邦人口の社会生物学的研觉, 比族 微生, $11: 5,359$, 炤 28.11.

6. 舘稳: 人口問題, 公衆衙生学, 第 1 楫第 3 繶, 日本臨牀社刊, 沿 23.1 .

7. 厚生大臣官房統計铜查部：第 8 回生命表, （1947）沿 25.9.

8. 厚生大臣官房統計調査部：第 9 回生命装, （1950）炤 30.3.

9. 水島治夫, 楠川晃, 馬島雄二郎： 1948 1949 年拊県別生命表(第 4 回), 㣂生統訫, $5: 2,1$, 炤 27.2.

10. 石田保広：医師, 菡科医師の死因, 死亡率平 均余命及び將来の 医師の 推計, 日本医師会雑 誌, $34: 9,529$, 炤 30.11 .

11. 金光浩治：東鉄管们従業貝の人口学的研觉, （1952 年）生命衣，人口動態，死因の觡析，艮 族衙生，20:5,6, 95, 嘴29.3.

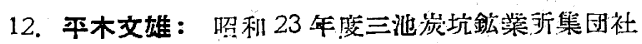
会居住者の生命表，尼族衙生，17:2，39，弨 25.6

13.上山教衙：特定死因による死亡者の生命蓄(炤

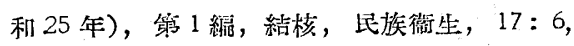
6, 138, 嘫 26.3 .

14.上山教篇：特定死因による死亡者の生命表（弨 和 25 年), 筙 2 絀, 肺炎, 下棵腸炎; 脳血管障 害, 比族鲖生, $18: 1,1$, 吱 26.5 .

15. 厚生大臣官房統計調查部：炤和 25 年に於ける 死亡統計，（1）年令階級別死亡率, 衡生統計, $5: 6,16$, 炤 27.6 .

16. 水島治夫, 楠川晃, 馬島雄二郎：炤利 24 年府 県别真正人口自然增加率，微生統計，5:6, 1, 炤 27.6 .

17. 水島治夫：本邦に於ける真の人口自然睄加率， 日新医学, 26:12, 炤 12.12.

18. T.N. E., Greville: Length of Life (L.I. Dublin, A. J. Lotka and M. Spiegelman 1949).

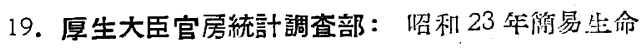
表, 微生統部, 4:1,2, 炤 26.1.

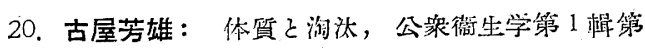
4 縌, 149，炤 23.1.

21. 原広之: 生存比（Survival Ratio）につけて， 比族副生，17:5，89，炤 25. 12. 


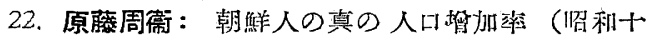
年)，此族哄生，9:3，147，炤 16.8 .

-23. 水島治夫，楠川晃，隆：炤利 22 年府県别 真正人口自然喕加綮，衔生統計， $4: 8 ， 1$, 炤 26. 8.

24. 人口售朋幾, 厚生の指琶, $2: 4$, 沿 30.11 .

25. 久保秀史：乳兒死亡の性比について，民旅衙 生, $11: 4,235$, 嚾 18.9.

26. 丸山博：乳兒死亡の統計的分析，省生統計， $4: 6,26$, 溜 26.6 .

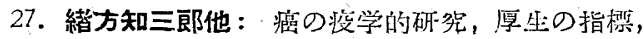
$2: 7,2$, 炤 30.7 .

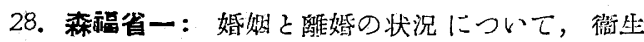
統計， 2: 1，18，贻 24.8

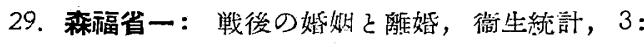
1, 18, 炤 25.1 .

30. 森福省一：婚娰 そ雖婚の鼠近の傾向，厚生の 指㮮，3:4, 16, 炤 31.4 .
31. 水鼻治夫：本那に於ける出生奖に゙及ぼす社会

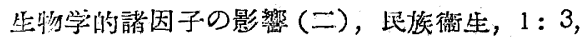
40 , 炤 6.8 .

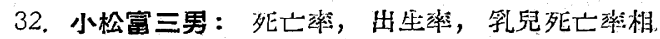
互間の相関倸数について，比族衛生，7:1,47， 㗁 14. 3.

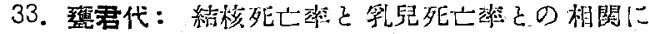
ついて，本邦結核死亡率及び乳兒死亡率に及ほ” 寸社会的因子の影䎂, 衡生統計, 4:9,21, 炤 26. 9.

34. 金光正次，米田達夫，宮下俊：絬核死亡の

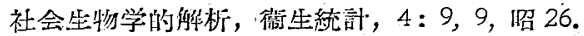
9.

35. 靑木隆一：全結核死亡竹を好ぐる因子の相閶: 関保の达的分析, 商生統計, $4: 2,22$, 照 26. 2.

36. 久保秀史：近年の乳幼兒死亡率低下の原因に

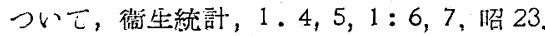




\section{A SOCIO-ECONOMIC STUDY ON THE STERILIZATION AND THE ARTIFICIAL PREGNANCY INTERRUPTION WITH SPECIAL REFERENCE TO THE MOTIVE AND EFFECT}

$\mathrm{By}$

\section{Tomohiko Koya, M.D.}

This article contributes to the information of sterilization and induced abortion which are very prevalent and represent important factors of the precipitous decrease of the birth rate in the present Japan. The author made a detailed investigation on the motivation, reason, and the result; one of the most interesting findings was that the women, generally speaking, used to resort to the sterilization operation under the condition of their having one or two male children already. Another finding must also be of value, that when women resort to induced abortion, the next baby will come to them very soon. For this reason, the author wants to emphasize that "it is not clever" to take the induced abortion for the purpose of birth control, not to say the other disadvantages.

\section{A DEMOGRAPHIC STUDY ON THE INHABITANTS IN IBARAKI PREFECTURE}

\section{BY \\ Takako Arakawa}

In an endeavor directed to a wider and higher synthesis of biological, medical and social factors in dealing with the public health problem, the authoress investigated the demographic phenomena as diagnostic indices of the public health condition in Ibaraki Prefecture. The result is summarized as follws:

1. In the first chapter, demographic data of the census in 1950 were handled and an abridged life table for Ibaraki Prefecture was made out.

2. In the second chapter, the authoress traced the movement of population and the change with age of the principal causes of death in Ibaraki Prefecture. - 3. In the third chapter the authoress she studied socio-biologically the population groups in urban as well as rural districts in Ibaraki Prefecture. She concluded that the increase of a capacity of population in irural paris of this prefecture had attained the utmost limit, and a balance of population had naturally to be kept by the increase in movement of population to urban districts.

(From the Department of Public Health, Scoool of. Medicine, Toho University.) 